\title{
NOTES
}

\section{A NEWLY DISCOVERED WHITMAN POEM ABOUT WILLIAM CULLEN BRYANT}

In the June 23, 1842, issue of the penny newspaper New Era, Parke Godwin, who had married the daughter of New York Evening Post editor William Cullen Bryant earlier in that year and had been working as an editor at the Post, announced that he was taking over the New Era as editor and would turn the daily in the direction of greater coverage of literature and the arts as well as the usual politics, commerce, and other fare. ${ }^{1}$ Godwin had initially planned to start a morning Democratic paper, the New York Morning Post, but instead bought the Nerw Era with $\$ 6000$ given to him by Bryant. The investment was not successful-it was very difficult to establish a cheap Democratic paper in this period-and the New Era apparently issued its last paper in August of 1842. Godwin would go on to start an equally short lived weekly called the Pathfinder in early 1843, before returning to work at the Evening Post. ${ }^{2}$ During the brief time Godwin was editor of the New Era, however, a poem by W.W. entitled "To Bryant, the Poet of Nature," appeared (July 26, 1842), identified as written "For the New Era." ${ }^{3}$ Like Whitman's other early poetry, its theme and style does not point in any direct way toward his achievements in Leaves of Grass, but, in addition to contributing to our understanding of his thinking about Bryant, it demonstrates how his poetry-like his prose-was embedded in and even at times resistant to prevailing Democratic aesthetics.

The argument for the poem being Whitman's is founded on his initials, his poetics both prior to and after Leaves of Grass, and his relationship to editors of political presses in these years. In order to establish this last point, that the appearance of this poem by Whitman at this time in this paper was not a random occurrence, it is necessary to establish a rather dense network of names and relationships. The previous editor of the New Era, Levi D. Slamm, was a well-known Democratic politician and trade unionist, who, contrary to Godwin's implication, had in fact published at least brief notices of literature in his paper-as when Slamm mentioned Walter Whitman's stories in the November 1841 and May 1842 issues of the Democratic Review, calling the latter one "beautiful." However, Slamm's favorite poet was Barnabas Hallock (who initially signed his poems B.H.), a Brooklyn cousin of poet Fitz-Greene Halleck who went on to become a government clerk and whom Slamm called a "mechanic poet" in reference to his job as a maker of stove patterns. ${ }^{5}$ When Slamm on June 13th announced his retirement from the New Era to start the daily Plebeian, he included paragraphs from the Aurora and the Evening Post that wished him success with the new enterprise and commented on his gentlemanly character, despite the abuse he had received-the New York Herald had been particularly brutal toward Slamm, turning his name into a byword, "Slamm, Bang, Ming \& Co.," for opportunistic locofoco politicians. ${ }^{6}$ 
Whitman had been hired as editor of the two-cent Aurora by publishers Anson Herrick and John F. Ropes by March 28, 1842, though he only lasted as editor through late April; he had a similarly short tenure at the Democratic Statesman in 1843. Herrick, who published both the daily Aurora and the weekly Sunday Atlas, hoped that the Aurora might become the organ in the city for John Tyler's candidacy for the presidential nomination, and perhaps Whitman's editorials did not quite suit the purpose. ${ }^{7}$ In any case, though an editor other than Whitman was likely the author of the Aurora's praise of Slamm in June, the notice is still evidence of how small (and factionalized) the circle of editors and writers for the Democratic press was-Herrick, like Slamm, was an active politician and Democratic alderman who would later become a Congressman. ${ }^{8}$ It's thus not surprising that John Bigelow, later an editor for the Evening Post, would also write news paragraphs for Slamm's Plebeian, and that in May 1844 Slamm's Plebeian would absorb the Aurora. Before that merger, the Aurora had absorbed The Union, another Tyler organ, which was edited by Mordecai M. Noah, who then went on to edit the Weekly Messenger. That paper merged with the Sunday Times, a weekly some scholars say was edited by Walter Whitman briefly in 1842-1843, to become the Times and Weekly Messenger, where Whitman would publish a story, article, and poem, all signed W. ${ }^{9}$ Whitman also continued to write for Herrick's Sunday Attas, sometimes under the pseudonym Aristides. ${ }^{10}$

A few days after announcing his editorship of the New Era, Godwin added his own praise of Slamm's Plebeian for continuing to avoid "personalities," or personal insults of the kind the Herald specialized in and often aimed at fellow editors. In the same commentary, Godwin notes that Herrick \& Ropes had disposed of their interest in the Washingtonian, a temperance journal that published a Whitman story in January of $1843 .{ }^{11}$ Whitman would later misidentify Parke Godwin as the editor who asked him to write a different temperance story (it was actually Park Benjamin for his weekly the New World, where Whitman also published poems in 1841 and 1842 under the initial W), but his confusion reinforces the fact that Whitman and Godwin were in contact about his writing during the early 1840s. The New World advertised in the New Era, for that matter, and Godwin praised Park Benjamin and his publications in that newspaper. And, as was customary, Godwin-like Slamm - noticed new issues of the monthly magazines, including pointing out on June 30,1842 , that the Democratic Review "has a pleasant tale by Walter Whitman, as we infer, from the initials attached to it." 12 And on July 26, 1842, the poem by W.W. appears as an original contribution to the New Era.

There were other poets with these initials active in this period-William Winter, or William (Ross) Wallace, for example - and Whitman seems most often in this period to sign his newspaper poems with just W, but Godwin's awareness that he used W.W. for the Democratic Review might explain the switch here. In addition, Whitman's personal and professional acquaintance with Godwin and Bryant (the Evening Post in 1842 reprinted one of his stories) and Bryant's importance to him as a model for his poetic, journalistic, and even political work, points to Whitman as the author. ${ }^{13}$ The poem also fits with the concerns of his other poetry of the period-in particular, the themes of 
death and fame-and the language of the poem (his diction and juxtapositions) recurs in some of his later considerations of death, as in "Brother of All, With Generous Hand" and "Ah, Not this Granite Dead and Cold." Here is the entire poem:

To Bryant, the Poet of Nature.

Let Glory diadem the mighty dead-

Let monuments of brass and marble rise

To those who have upon our being shed

A golden halo, borrowed from the skies,

And given to time its most enduring prize;

For they but little less than angels were:

But not to thee, oh! nature's OWN, we should

(When from this clod the minstrel-soul aspires

And joins the glorious band of purer lyres)

Tall columns build: thy monument is here-

For ever fixed in its eternity-

A monument God-built! 'Tis seen around-

In mountains huge and many gliding streams-

Where'er the torrent lifts a melancholy sound,

Or modest flower in broad savannah gleams.

In the context of Whitman's early poetry, one might note his continued interest in achieving poetic fame (rather than concerns with nature per se), or in the Glory he refers to in "Fame's Vanity" (1839, Long Island Democrat). He observes that some people achieve renown and others oblivion, and that one must "build up" a lofty name, upon which the ranks of men will fix "their reverent gaze," as they might upon a raised monument. He also employs the old-fashioned "thou" in conjunction with soul and the exclamatory "O""Thou foolish soul...O what happiness is lost" - and concludes that, rather than striving to gain newspaper puffs with their false critical praise, he will forget about a monument (no "markless resting stone" for him) and instead be satisfied with a more democratic (mighty and lowly all sleep there) earthy couch. ${ }^{14}$ In "My Departure" (1839, Long Island Democrat) too, he prefers his death to come where "flowers bloom," looking on "water, sun, and hill, / As on their Maker's very face." 15 And again, in "The End of All" (1840, Long Island Democrat), "O fool" "builds a mighty name" and rears "tower aspiring glory" for just an hour of fame, which is contrasted to the permanence of the earth. ${ }^{16}$

This sort of language continues in 1842, when he revises "Fame's Vanity" as "Ambition" (1842, Brother Fonathan) and describes "Glory's prized caress," warning that the dream of having "thick countless ranks of men" gaze on "thee" is just "airy castles." 17 And in "Time to Come," in Aurora (March 1842), he calls "O, Nature" to answer where the soul should abide; in August 1842's "No Turning Back" (published while he was perhaps editor of the Sunday Times), he describes a man who, possessing renown, "Towered" over all the multitude. ${ }^{18}$ Much later (though still in a newspaper poem), "Brother 
of All, With Generous Hand" (1870, Galaxy), Whitman returns to a burial verse for "thee." 19 Pondering over the tomb of a millionaire stockbroker who missed out on the glory awarded to other men, Whitman compares it to the graves of heroes, with their statues of the famous dead (including poets), the giants for whom monuments of "marble and brass" have been bodied. But the speaker turns from them to the ordinary and everyday domestic scenes of the city, with laborers, mechanics, and other ordinary people, scenes which are gifts of the Earth, with its "mountains, fields and rivers," an expansiveness akin to the generosity of the philanthropist. In "Ah, Not This Granite Dead and Cold," also published in a newspaper (1885, The Philadelphia Press), he continues this theme which he first established in this poem on Bryant (and on McDonald Clarke, as will be noted below) in $1842 .{ }^{20}$ The poem rejects the recently erected granite obelisk to George Washington in Washington D.C.a sizable stone marker - as insufficient or inadequate, because "Wherever Freedom" stands or is rising, is "thy true monument." In his draft for the poem, he employed the contraction "where'er," just as he did in the poem to Bryant, and though the poem's conclusion stresses Washington's republican legacy, the poem initially, in a style more similar to the poem on Bryant, grants as Washington's monument the continent, every part, frozen North or sultry South..$^{21}$ A parenthetical question and answer in the middle of the poem mediates this transition from a description of the earth to the realm of law and human patriotism.

So the poem to Bryant, like much of Whitman's early and later newspaper poetry, pursues this idea of the rejection of fame and its ability (signified by monuments, obelisks, stone, brass, and marble) to raise one to a lofty position, from which one can receive the reverence of the multitude, and the acceptance of what seems (but in fact is not) a lowlier place with the modest flowers on the broad (flat, not towering) savannah or grassy bank. But this poem is also in dialogue with yet a third newspaper poet, McDonald Clarke. Whitman's poem "The Death and Burial of McDonald Clarke: A Parody" appeared in the Aurora in March, 1842, while Whitman was editor. ${ }^{22}$ Most of the newspapers, in noticing Clarke's death in one way or another, commented on the lesson his life and death taught-Slamm in the New Era pointed out that Clarke never wanted any "picnic patronage." ${ }^{23}$ Whitman in his poem on Clarke considers (albeit in a parody) the proper monument for the satirical and impoverished poet, who was said to have squandered a fortune giving relief to others-enough to award him the epithet the "mad poet." ${ }^{24}$ Whitman opens with a play on "tombs"- which was the nickname for New York City's Egyptian-revival style prison - and ends by saying that Clarke "needs not a stone" as his name will linger in story, encircled with glory.

McDonald Clarke himself regarded monuments sardonically. His "The Marble Statue" (1835, Sun; also published in Noah's Evening Star) describes the statue of Alexander Hamilton in the rotunda of the Merchant's Exchange in Wall Street - a statue later destroyed in a fire-as having been raised on its throne by Commerce, from whence it cast its sceptered spell of stone over the gazing crowd. ${ }^{25}$ The Whig Morning Courier and Enquirer called Clarke's poems beneath criticism, to which the Herald-which commissioned Clarke 
to write poems - responded that the Courier and Enquirer's critic was madder than Mac himself. ${ }^{26}$ Indeed, the Herald, which by 1840 was shifting away from some of its anti-Democratic positions, called Clarke's work original, witty, sarcastic, and poetic, exhibiting more real genius than half the newspaper poetry ever published, with a style of healthy vigor that put him at the head of American poetry as the only true poet that the democratic age of literature had yet discovered. Bryant, the Herald continued, had some poetry, but it was the poetry of cliques, of books, of narrow localities, of certain schools, not the poetry of nature, either social, physical, or civilized, in all its variety and grandeur. ${ }^{27}$ In the following week, the Herald published (and illustrated with a woodcut) a Clarke poem on "Dick Dropsy, an Office Beggar," a dandy and politician who lived on credit begging for government (picnic?) patronage, who could be spotted at the Astor House and resembled some 5,000 editors, writers and critics in the city. ${ }^{28}$

Whitman surely read the two-penny Herald; even Slamm did, and he often agreed with James Gordon Bennett despite Bennett's abuse. ${ }^{29}$ Whitman would have understood that there were two claimants to the title (fame?) of founder of American democratic poetry-eccentric genius Clarke with his language of loafers and urban topicality, or Bryant with his more lyrical language of nature. In his poetic tributes to Clarke and to Bryant, just a few months apart, one dead and one still living, Whitman adopts (or tries out) the preferred modes of the two authors. John Burroughs, in his review of Drum-Taps in the Galaxy, where "Brother of All" appeared four years after, notes that Whitman, while working as an editor in New York, was in the habit of taking long walks with Bryant in and about Brooklyn. ${ }^{30}$ Perhaps it is not surprising that Bryant would, at least in the newspapers, win the contest with Clarke.

University of Nebraska-Lincoln

WENDY J. KATZ

\section{NOTES}

1 New Era (June 23, 1842), 2. The masthead at this time loses the classical liberty temple that had decorated it.

2 On Godwin and Bryant, see Gilbert H. Muller, William Cullen Bryant: Author of America (Albany: State University of New York Press, 2008), 175. The weekly Pathfinder was published and edited by Godwin from February 25 (no.1) 1843-June 3 (no. 15), 1843; John Bigelow became associate editor at the Evening Post by November 16, 1848. See Louis Hewitt Fox, New York City Newspapers, 1820-1850, A Bibliography (Chicago: University of Chicago Press, 1928), 78, 81-82.

3 W.W., "To Bryant, the Poet of Nature," New Era (July 26, 1842), 2.

4 New Era (November 19, 1841), 2; (May 10, 1842), 2. The Democratic Review advertised in the New Era.

5 New Era (December 2, 1841), 2. John W.M. Hallock, The American Byron: Homosexuality and the Fall of Fitz-Greene Halleck (Madison: University of Wisconsin Press, 2000), 27, only briefly mentions Barnabas. The New York City and Co-Partnership Directory (New-York: John Doggett, Jr., 1843), 150, lists him as making stovepatterns and living at 117 Madison. The New York City Directory (New York, 1844), 153, lists 
him as a clerk in the naval office, living at 117 Madison, and Trow's New York City Directory (New York: John F. Trow, 1859), 337, gives the naval job but a residence at 299 Atlantic in Brooklyn.

6 Slamm resigns, New Era (June 13, 1842), 2; New Era (June 16, 1842), 2, excerpts from the Evening Post and the Aurora. Alexander Ming, Jr., was a tavern owner who advertised in the New Era and was also active in locofoco politics. Peter Adams, The Bowery Boys: Street Corner Radicals and the Politics of Rebellion (Westport, CT: Praeger Publishers, 2005), xxii, 2-3, 71-76, observes that Mike Walsh, editor of the Subterranean (which published Whitman's "Lesson of the Two Symbols," July 15, 1843), was a Washington correspondent for the Aurora during Whitman's tenure as well as later a writer for the Herald, and led a faction of the locofocos that despised Slamm, who sued Walsh for libel in 1843 while editor of the Plebeian.

7 On Whitman as editor at the Aurora and the way in which the paper positioned itself against the New Era under Slamm, see Jason Stacy, Walt Whitman's Multitudes: Labor Reform and Persona in Whitman's fournalism and the First Leaves of Grass, 18401855 (New York: Peter Lang, 2008), 45-61. Whitman clearly differed from Slamm over the question of public funding for Catholic schools; "Organs of the Democracy," Aurora, March 29, 1842, rpt. in Herbert Bergman, et al., ed., The fournalism (New York: Peter Lang Publishers, Inc., 1998, 2 vols), 1: 79. Joseph Jay Rubin, The Historic Whitman (Pennsylvania State University, 1973), 88, 110, however, describes Whitman as friendly with Slamm and employed as a penny-a-liner on the Plebeian; and notes that Whitman's campaign paper the Democrat merged with the Plebeian in 1844 with Whitman's blessing. Rubin also cites Walter Whitman's 1843 editorship at the Statesman as being anti-Tyler (102). William Cauldwell, "Walt at the Daily Aurora: A Memoir of the Mid-1840s," in Gary Schmidgall, ed., Conserving Walt Whitman's Fame: Selections from Horace Traubel's 'Conservator,' 1890-1919 (Iowa City: University of Iowa Press, 2006), 80-82. Bergman, "Introduction," The fournalism, lv-lvi, says that in the summer of 1842 Whitman was editing the Evening Tattler and writing for the Sunday Times.

8 Anson Herrick did not become an Alderman until 1854 and Congressman until 1863, where as a Democrat he voted to abolish slavery. John T. Hubbell and James W. Geary, eds., Biographical Dictionary of the Union: Northern Leaders of the Civil War (Westport, CT: Greenwood Press, 1995), 250-251.

9 Fox, New York City Newspapers, 18-19, 81-82, 112, 103; the Plebeian also in 1844 absorbed the Democrat, another paper Whitman worked for. See M. Jimmie Killingsworth, "Whitman's Journalism," in J.R. LeMaster and Donald D. Kummings, eds., Walt Whitman: An Encyclopedia (New York: Garland Publishing, 1998), and Susan Belasco, ed., with Elizabeth Lorang, "Whitman's Poems in Periodicals," available at the Walt Whitman Archive (whitmanarchive.org).

10 Aristides (Whitman) did a series of articles titled "Brooklyn Affairs" in the New York Sunday Atlas in 1850 that has not previously been documented, though his work for the Atlas under this pseudonym is known: January 6, p. 2; February 10, p. 3; February 23, p. 3; March 17, p. 3; March 31, p. 3; April 14, p. 3; April 21, p. 2; April 28, p.3; May 5, p. 2; May 12, p.1. The articles contain a small amount of personal (biographical) information. Aristides was a popular name for correspondents writing to Whig as well as Democratic newspapers. The New Era in 1841 had a correspondent with that name who wrote about the odious despotism of the court of chancery as well as an Aristides who disapproved of the Tribune's scolding of poet and editor George P. Morris; the Express in 1841 had a series under that name as well; the Courier and Enquirer 
published Demosthenes' letter responding to Aristides' letter of January 13, 1841, in the Times and Star; and the Daily News in 1857 had a Colonel Doheny writing under that name. Whitman also contributed to Thomas Dunn English's Aristidean, a shortlived magazine English founded in 1845, after a stint as editor of the Aurora in 1844.

11 New Era (June 28, 1842), 2.

12 New Era (June 30, 1842), 2, on Park Benjamin; New Era (July 27, 1842), 2, on Whitman. W. W., "A Legend of Life and Love," United States Democratic Review 49 (July 1842), 83-86.

13 Allan Nevins, The Evening Post: A Century of fournalism (New York: Boni and Liveright, 1922), 224. On Bryant as a model for Whitman, especially in regards to graveyard poetry, see Kenneth M. Price, Whitman and Tradition: The Poet in His Century (New Haven: Yale University Press, 1990), 56-61.

14 Whitman, “Fame's Vanity," Long Island Democrat (October 23, 1839), 1. Available at the Walt Whitman Archive (whitmanarchive.org).

15 Whitman, "My Departure," Long Island Democrat (November 27, 1839), 2. Available at the Walt Whitman Archive (whitmanarchive.org).

16 Whitman, "The End of All," Long Island Democrat (September 22, 1840), 1. Available at the Walt Whitman Archive (whitmanarchive.org).

17 Whitman, "Ambition," Brother Fonathan 1 (January 29, 1842), 113. Available at the Walt Whitman Archive (whitmanarchive.org).

18 Whitman, "Time to Come," Aurora (April 9, 1842), 1; Whitman, "No Turning Back," Sunday Times (August 14, 1842), 1. Available at the Walt Whitman Archive (whitmanarchive.org).

19 Whitman, "Brother of All, With Generous Hand," Galaxy 9 (January 1870): 7576. Available at the Walt Whitman Archive, (www.whitmanarchive.org). On Whitman and cemetery monuments, see Desirée Henderson, "What is the grass?': The Roots of Walt Whitman's Cemetery Meditation," Walt Whitman Quarterly Review 25:3 (Winter 2008), 89-107; and more generally Harold Aspiz, So Long! Walt Whitman's Poetry of Death (Tuscaloosa: University of Alabama Press, 2004). In Whitman's writings on Greenwood Cemetery in Brooklyn, he refers to the grave of poet McDonald Clarke, "A Visit to Greenwood Cemetery," Sunday Times $\mathcal{E}$ Noah's Weekly Messsenger (May 5, 1844), and "An Afternoon at Greenwood" (June 13, 1842), Brooklyn Daily Eagle, rpt. Bergman, The fournalism, 190-191, 421-423.

20 Whitman, "Ah, Not This Granite Dead and Cold," The Philadelphia Press (February 22, 1885). Available at the Walt Whitman Archive (whitmanarchive.org).

21 Whitman, poetry manuscript. Available at the Walt Whitman Archive, (whitmanarchive.org). Bergman attributes to Whitman "Some Thoughts About This Matter of the Washington Monument," Brooklyn Daily Eagle (October 18, 1847), rpt. The fournalism, 2: 340-341, which says Washington doesn't need the "cold pomp of marble."

22 Whitman, "The Death and Burial of McDonald Clarke," New York Aurora, March 18, 1842:1. Available at the Walt Whitman Archive, (whitmanarchive.org). "Death of McDonald Clarke," Aurora (March 8, 1842), and "McDonald Clarke," Aurora (March 12, 1842), rpt. in Bergman, The fournalism, 1:46-48, 51-52, say that the author was not personally acquainted with the poet, and that though Clarke was ridiculed by the vulgar, he drew "bold, startling images" that entitle him to the title of poet, and 
quotes Clarke's poem "The Dead Poet" to the effect that the "human heart" is the only monument the poet wants. Clarke apparently submitted a poem to the Aurora.

23 New Era (March 7, 1842), 2. McDonald Clarke's 1836 poetry book was published by Jared W. Bell, who had been proprietor and publisher of the New Era at the start of Slamm's tenure.

24 "Genius in the Blues," Constellation (August 24, 1833), 2.

25 “The Marble Statue," Sun (April 30, 1835), 1; also published in Noah's Evening Star (April 25, 1835), 1. The statue was by sculptor Ball Hughes.

26 Morning Courier and Enquirer (September 13, 1836), 2; Herald (September 14, 1836), 2 .

27 Herald (December 24, 1840), 2.

28 Herald (December 29, 1840), woodcut and poem on p. 1, editorial on p. 2.

29 In New Era (June 6, 1840), 2, for example, Slamm took the Herald's side in the "moral war" waged against the Herald by the Wall Street press, led by the Courier and Enquirer.

30 "The New York Press," Aurora (March 29, 1842), rpt. Bergman, The fournalism, 1:81-82. John Burroughs, "Walt Whitman and His 'Drum Taps," Galaxy 2 (December 1, 1866), 606-615. Available at the Walt Whitman Archive (whitmanarchive.org). 